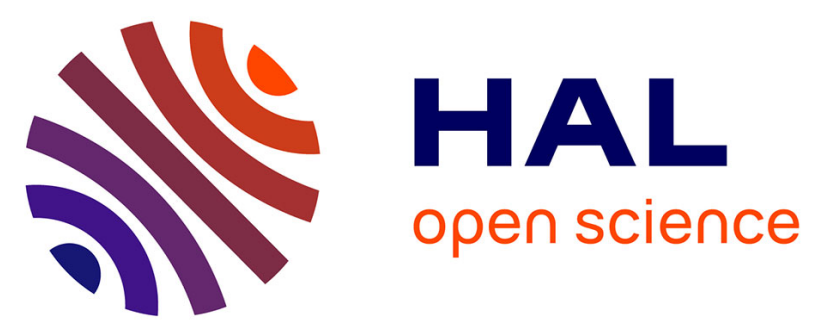

\title{
Localization of a potassium channel gene (kcne1) to 21q22.1-q22.2 by insitu hybridization and somatic-cell hybridization
}

Christophe Chevillard, Bernard Attali, Florian Lesage, Michel Fontes, Jacques Barhanin, Michel Lazdunski, Marie Geneviève Mattei

\section{To cite this version:}

Christophe Chevillard, Bernard Attali, Florian Lesage, Michel Fontes, Jacques Barhanin, et al.. Localization of a potassium channel gene (kcne1) to 21q22.1-q22.2 by insitu hybridization and somatic-cell hybridization. Genomics, 1993, 15 (1), pp.243-245. 10.1006/geno.1993.1051 . hal-01593104

\section{HAL Id: hal-01593104 \\ https://hal-amu.archives-ouvertes.fr/hal-01593104}

Submitted on 5 Dec 2018

HAL is a multi-disciplinary open access archive for the deposit and dissemination of scientific research documents, whether they are published or not. The documents may come from teaching and research institutions in France or abroad, or from public or private research centers.
L'archive ouverte pluridisciplinaire HAL, est destinée au dépôt et à la diffusion de documents scientifiques de niveau recherche, publiés ou non, émanant des établissements d'enseignement et de recherche français ou étrangers, des laboratoires publics ou privés.

\section{(c)(1)}

Distributed under a Creative Commons Attribution| 4.0 International License 


\section{Localization of a Potassium Channel Gene (KCNE1) to 21q22.1-q22.2 by in Situ Hybridization and Somatic Cell Hybridization}

Christophe Chevillard, ${ }^{*}$ Bernard Attali, $\dagger$ Florian Lesage, $\uparrow$ Michel Fontes, ${ }^{*}$ Jacques Barhanin $\uparrow$ Michel Lazdunski, $\dagger$ and Marie Geneviève Mattei*

*INSERM U242, Faculté de médecine de la Timone, Bd I. Moulin, 13385 Marseille, France; and tInstitut de pharmacologie moléculaire et cellulaire, 660 route des Lucioles, 06560 Valbonne, France

Received June 24, 1992; revised October 8, 1992

$\mathrm{K}^{+}$channels form a diverse family of membrane-spanning proteins that exhibit various electrophysiological and pharma-

${ }^{1}$ To whom correspondence should be addressed. Telephone: 33-191-78-44-77. Fax: 91-80-43-19.

GENOMICS 15, 243-245 (1993) $0888-7543 / 93 \$ 5.00$ Copyright (C) 1993 by Academic Press, Inc. All rights of reproduction in any form reserved. 
cological properties (5). They play a prominent role in a wide variety of biological functions such as cell growth, osmotic regulation, hormonal secretion, and excitability (5). Among the various $\mathrm{K}^{+}$channel proteins characterized, the KCNE1 protein is distinct from the Shaker-type channels in its structure and biophysical properties (for review, see 6). It consists of 129-130 amino acid residues with a single putative transmembrane domain and directs the expression of a very slow activating voltage-dependent $\mathrm{K}^{+}$current $(4,7)$, when expressed in Xenopus oocytes. Originally characterized in epithelial cells (7), KCNE1 has also been cloned from neonatal heart, uterus, and human $\mathrm{B}$ and $\mathrm{T}$ lymphocytes (1-3). Its presence in human $T$ lymphocytes suggested that the KCNE1 protein could be involved in the $\mathrm{T}$ cell activation process (1). In the present work, we mapped the KCNE1 gene by in situ hybridization on human metaphase chromosomes and Southern blot analysis of human-Chinese hamster cell hybrids.

The HIsK clone (a cDNA clone coding for KCNE1), containing an insert of $436 \mathrm{bp}$ in a Bluescript vector, was labeled by nick translation to a specific activity of $4.7 \times 10^{7} \mathrm{dpm} / \mu \mathrm{g}$. The radiolabeled probe was hybridized on metaphase spreads at final concentration of $25 \mathrm{ng} / \mathrm{ml}$ of hybridization solution. In situ hybridization was carried out on chromosome preparations obtained from phytohemagglutinin-stimulated human lymphocytes cultured for 72 h. 5-Bromodeoxyuridine was added for the final $7 \mathrm{~h}$ of culture $(60 \mathrm{mg} / \mathrm{ml}$ of medium), to ensure a posthybridization chromosomal banding of good quality. After coating with nuclear track emulsion (Kodak NTB2), the slides were exposed for 10 days at $4^{\circ} \mathrm{C}$ and then developed. $\mathrm{R}$-banding was performed by the fluorochrome-photolysis Giemsa (FPG) method and metaphases were rephotographed before analysis.

A panel of human-hamster somatic cell hybrid DNA, digested with $E c o$ RI, was purchased from BIOS Corp. (New Haven, $\mathrm{CT}$ ). The filters were prehybridized in $6 \times \mathrm{SSC}, 5 \times$ Denhardt's, $1 \% \mathrm{SDS}$, and $100 \mathrm{mg} / \mathrm{ml}$ denaturated salmon sperm DNA for $2 \mathrm{~h}$. Filters were hybridized in the same buffer supplemented with $10^{6} \mathrm{cpm} / \mathrm{ml}$ radiolabeled probe and washed in increasingly stringent solutions. The final washing conditions were $0.1 \times \mathrm{SSC}, 1 \% \mathrm{SDS}$ at $65^{\circ} \mathrm{C}$. Filters were exposed for $2-5$ days.
Three slides, hybridized with the HIsK probe, were analyzed: In the 350 metaphase cells examined after in situ hybridization, there were 831 silver grains associated with chromosomes and $69(8.3 \%)$ were located on chromosome 21 . The distribution of grains on this chromosome was not random, and a small, but reproducible, hybridization peak was detectable: $78.2 \%$ of grains on chromosome $21(54 / 69)$ mapped to q22 band of this chromosome, with a maximum on $q 22.1$ and q22.2 (Fig. 1).

As the percentage of silver grains on chromosome 21 was not very high, we confirmed the localization of this probe using a somatic cell hybrid panel. On the Southern blot we could see that the probe gives a unique signal in human $(10.5 \mathrm{~kb})$ as well as in hamster $(6 \mathrm{~kb})$ DNA and we observed that the probe perfectly segregated with chromosome 21 , confirming the in situ hybridization data.

In summary, we employed two independent procedures (the use of a somatic cell hybrid panel and in situ hybridization) to map the potassium channel gene KCNE1. Our results indicate that this gene is located on chromosome 21 , at $21 \mathrm{q} 22.1$ or $21 \mathrm{q} 22.2$. Although chromosome 21 is the smallest human chromosome, it represents a clinically important region of the human genome since the presence of three copies of the normal chromosome (21 trisomy) leads to the appearance of Down syndrome. In addition to mental retardation and congenital heart disease, this syndrome is characterized by a consistent pattern of abnormal phenotype: physical development, alterated thymic function, increased susceptibility to leukemia, and premature aging with neuropathological brain lesions. The KCNE1 potassium channel is located in the distal part of this chromosome and included in the Down syndrome region. Interestingly, it has been reported recently that trisomy 21 dorsal root ganglion neurons from human tissue had a shorter duration action potential due to altered $\mathrm{K}^{+}$currents (8); However, the $\mathrm{K}^{+}$channels involved are more likely to belong to the Shaker-type family. The KCNE1 protein is not expressed in the nervous system but is found mainly in epithelial cells, uterus, neonatal heart, and lymphocytes. Such a distribution may parallel some of the clinical signs associated with Down syndrome, including cardiovascular malfunction, immunological disorders, and increased risk of leukemia (9).

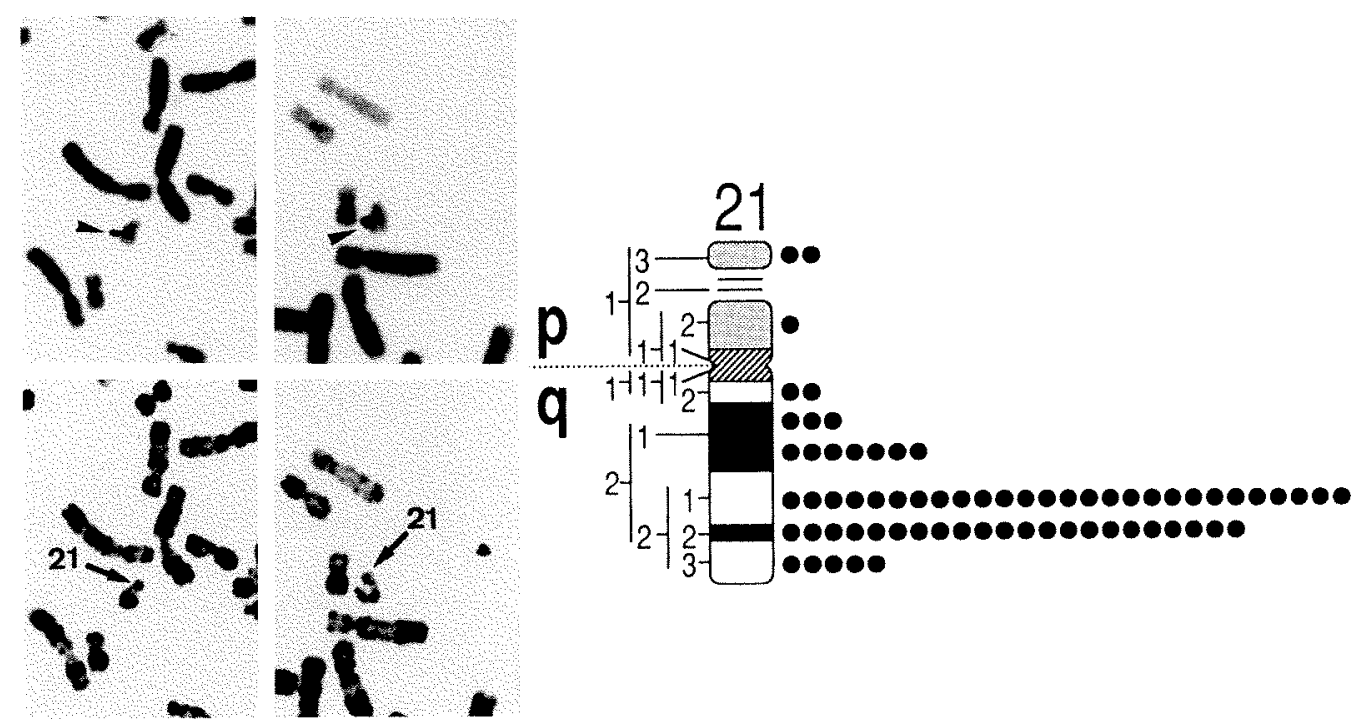

FIG. 1. Two partial human metaphases showing the hybridization to chromosome 21. Top: Arrowheads indicate silver grains on GiemsaFIG. 1. Two partial human metaphases showing the hybridization to chromosome 21 . Top: Arrowheads indicate silver grabequently identified by R-banding (FPG
stained chromosomes, after autoradiography. Bottom: Chromosomes with silver grains were subsequal technique). Right: Idiogram of the human G-banded chromosome 21 illustrating the distribution of labeled sites for the HIsK probe. 


\section{REFERENCES}

1. Attali, B., Romey, G., Honore, E., Schmid-Alliana, A., Mattei, M. G., Lesage, F., Ricard, P., Barhanin, J., and Lazdunski, M. (1992). Cloning, functional expression and regulation of two $\mathrm{K}^{+}$ channels in human T lymphocytes. J. Biol. Chem. 267: in press.

2. Folander, K., Smith, J. S., Antanavage, J., Bennett, C., Stein, R. B., and Swanson, R. (1990). Cloning and expression of the delayed-rectifier IsK channel from neonatal rat heart and diethylstilbestrol-primed rat uterus. Proc. Natl. Acad. Sci. USA. 87: 2975-2979.

3. Honore, E., Attali, B., Romey, G., Heurteaux, P., Ricard, P., Lesage, F., Lazdunski, M., and Barhanin, J. (1991). Cloning, expression, pharmacology and regulation of a delayed-rectifier $\mathrm{K}^{+}$ channel in mouse heart. EMBO J. 10: 2805-2811.

4. Murai, T., Kazikuka, A., Takumi, T., Ohkubo, H., and Nakanishi, S. (1989). Molecular cloning and sequence analysis of a human genomic DNA encoding a novel membrane protein which exhibits a slow activating potassium channel activity. Biochem. Biophys. Res. Commun. 161: 176-181.

5. Rudy, B. (1988). Diversity and ubiquity of $\mathrm{K}^{+}$channels. Neurosciences. 25: 729-749,

6. Rudy, B., Kentros, C., and Vega-Saenz de Miera E. (1991). Families of potassium channel genes in mammals: Toward an understanding of the molecular basis of potassium diversity. Mol. Cell. Neurosci. 2: 89-102.

7. Takumi, T., Ohkubo, H., and Nakanishi, S. (1988). Cloning of a membrane protein that induces a slow voltage-gated potassium current. Science 242: 1042-1045.

8. Nieminen, K., Suarez-Isla, B. A., and Rapoport, S. I. (1988). Electrical properties of cultured dorsal root ganglion neurons from normal and trisomy 21 human fetal tissue. Brain Res. 474: 246-254.

9. Epstein, C. J. (1986). "The Consequences of Chromosomal Imbalance: Principles, Mechanisms, and Models," pp. 253-323, Oxford Univ. Press, Cambridge/New York. 